\title{
AQUATIC INVERTEBRATES IN A SMALL NORTHERN LAKE
}

E. R. WHITING, Dept. of Zoology, University of Alberta, Edmonton, Alberta, E. A. DRIVER and D. G. PEDEN, Canadian Wildlife Service, Saskatoon, Saskatchewan

The invertebrate fauna of our small northern lakes can often be quite abundant and diverse, as we found while sampling Potato Lake for the availability of food for staging waterfowl in the spring of 1974. Potato Lake is a very small lake which is about 9 $\mathrm{km}$ south-east of the town of La Ronge, Saskatchewan, and which drains into LaC La Ronge. It is in boreal forest near the edge of the Canadian Shield. We collected only from the southern basin of the lake (which is joined to the main lake by a narrow channel) covering an area of about $11 / 4 \mathrm{~km}^{2}$ with a maximum depth of about $2 \mathrm{~m}$. There is a floating mat of vegetation extending out a couple of meters from the shore on which cattails (Typha latifolia) and horsetails (Equisetum sp.) grow in abundance. Elsewhere the bottom consists of a fine black ooze.

Samples were taken along several different transects at each of four depths: on the floating mat just off shore, on the floating mat near its outer edge, just off the floating mat in about three feet of water, and farther from shore in about four feet of water. Vertical strata of water, including bottom material to a depth of six inches were sampled using a Dendy sampler. Duplicate samples were taken from the sites at three different times: in late May, in mid-June, and in late June.

The samples (Table 1) contained about $2 / 3$ crustaceans, $10 \%$ insects and $12 \%$ seeds. Mollusks and annelids were also abundant. Daphnia pulex was by far the most abundant organism present, comprising nearly one half of all individuals collected. Other water fleas (Eurycercus and Daphnia similis), midge larvae, sideswimmers (Hyalella azteca), snails (Gyraulus), clams (Pisidium), copepods, seed shrimps
(Ostracoda), aquatic earthworms (Oligochaetes) and wild rice seeds were also abundant.

The water just off the floating mat contained the largest number of organisms, primarily because of the abundance of water fleas and copepods in the surface (limnetic) zone. One seven square inch stratum taken from this area contained one thousand individuals of Daphnes pulex. Samples taken from the floating mat were also quite well populated and contained somewhat more diverse fauna than the deeper water samples. The samples taken at the four foot depth contained considerable fewer organisms than the other samples.

Most of the abundant invertebrate taxa, were most frequently found in the vegetation of the floating mat. Daphnia pulex and the sideswimmers (Hyalella azteca) were most abundant just off the floating mat. The seeds were found to be the most abundant in the ooze of the deepest water samples.

The greatest numbers occurred at the second sampling time (in midJune) once again due to the abundance of water fleas. The other organisms were most abundant at the end of June at the third sampling time.

There appears to be an abundance of aquatic invertebrates, especially Daphnia and Hyalella, and seeds present to serve as food for waterfowl in this lake. This is of interest because the lake is an important staging area for Lesser Scaup and Ring-necked ducks during spring and especially fall migration. Large numbers of these birds were observed feeding in the open water of the lake in late May. There were also a number of Mallards and Teal in and along the floating mat, which probably remained on the lake to nest. 


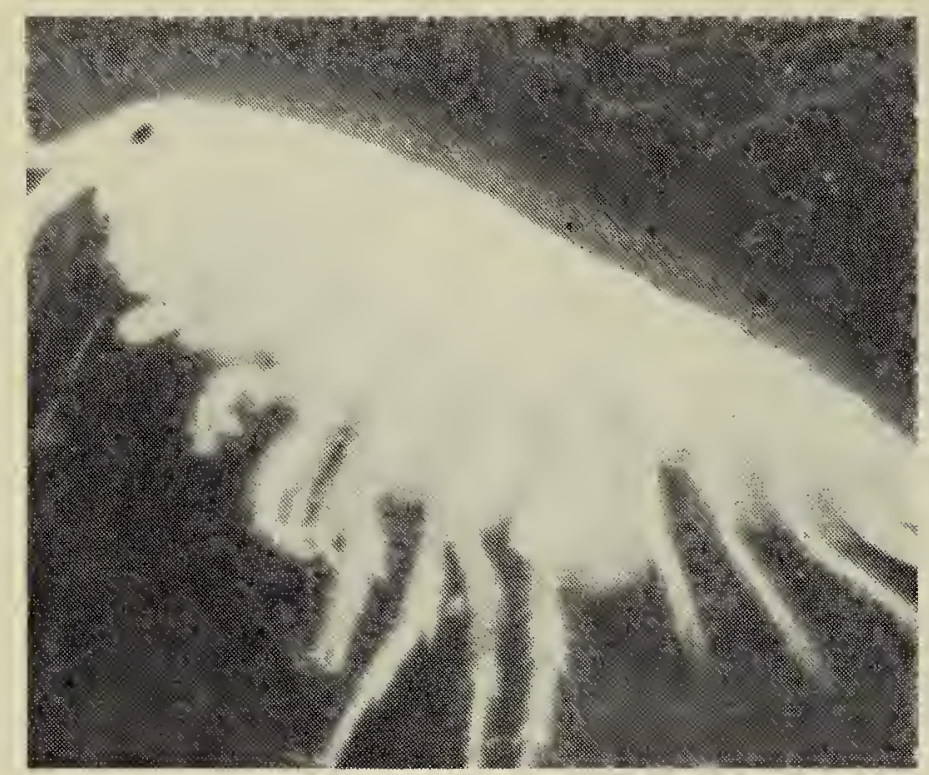

$1 \mathrm{~g}$

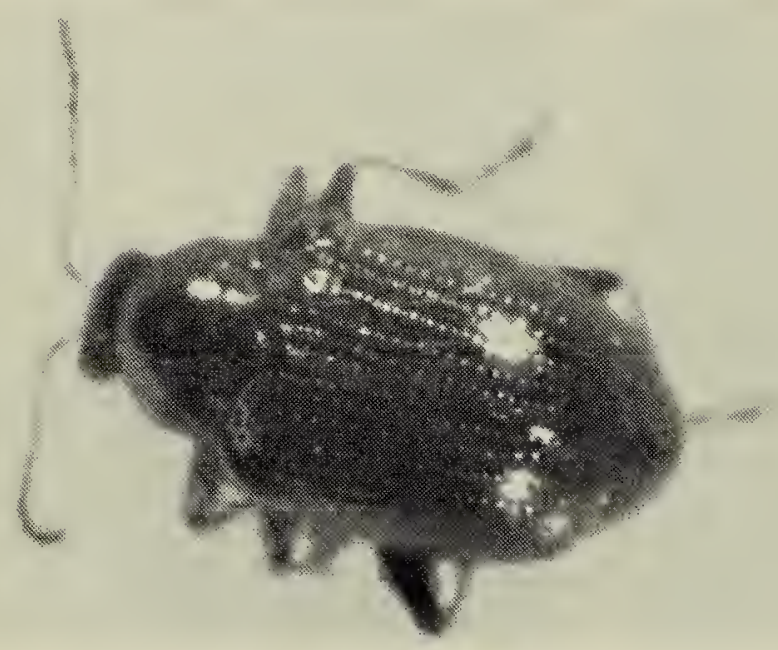

$1 i$

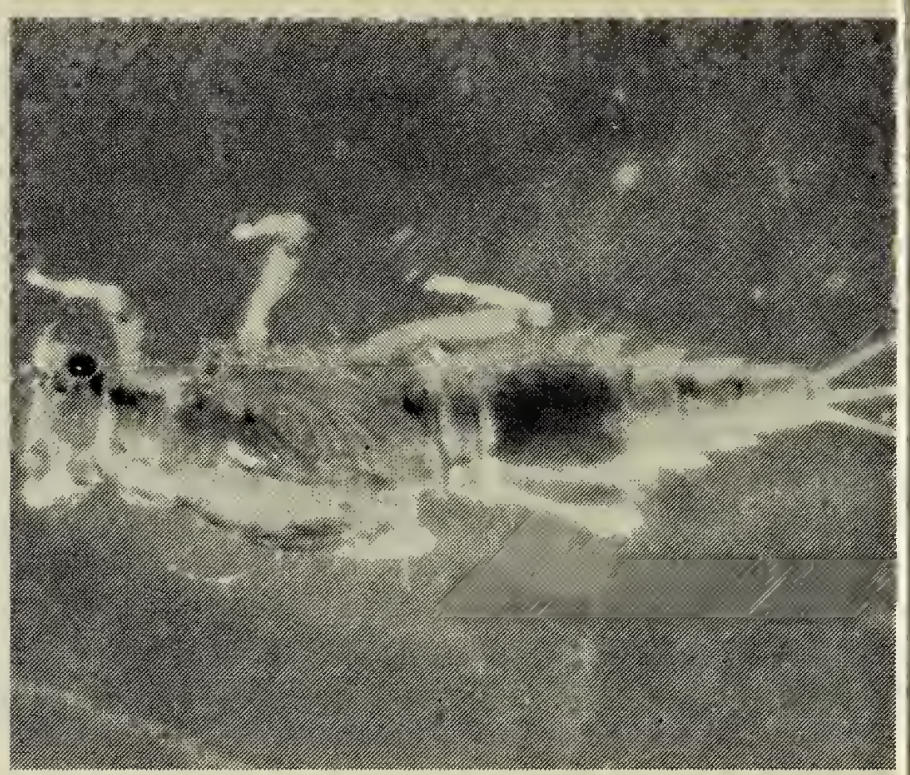

Th

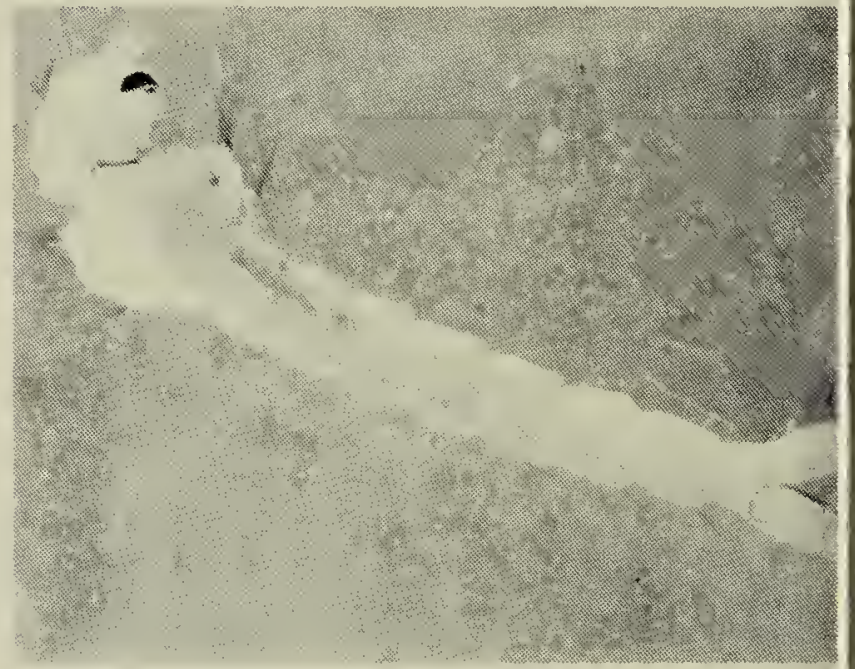

$1 \mathrm{j}$

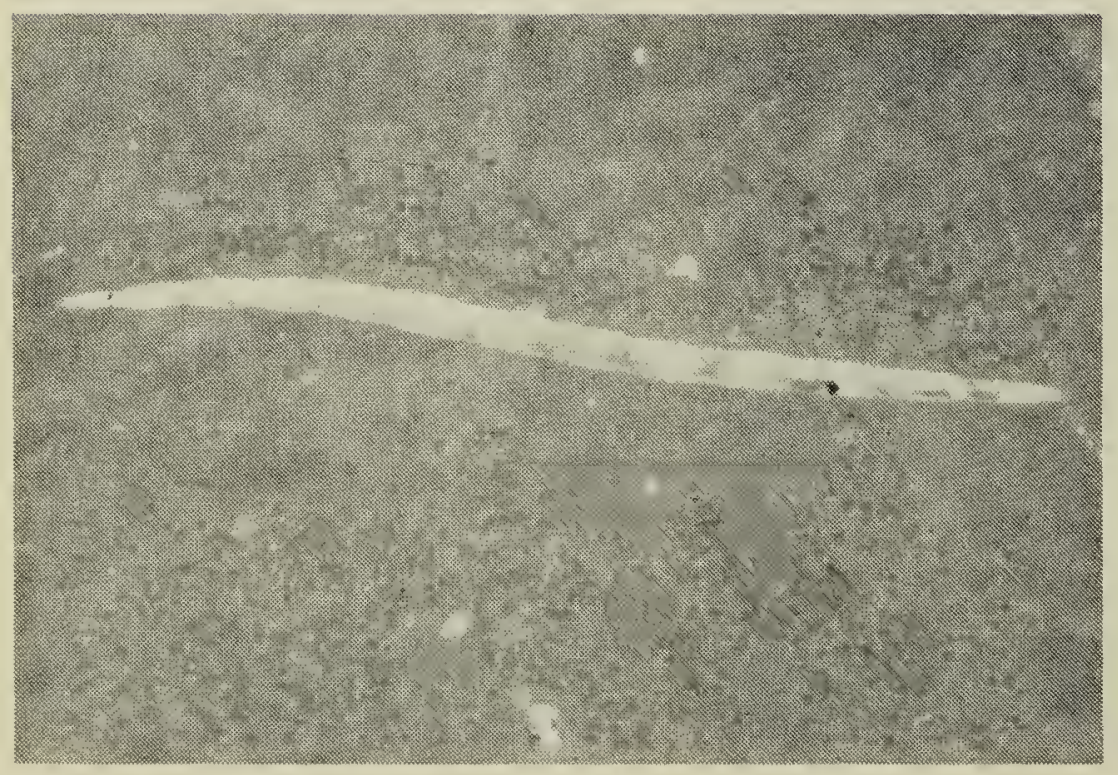

$1 \mathrm{k}$

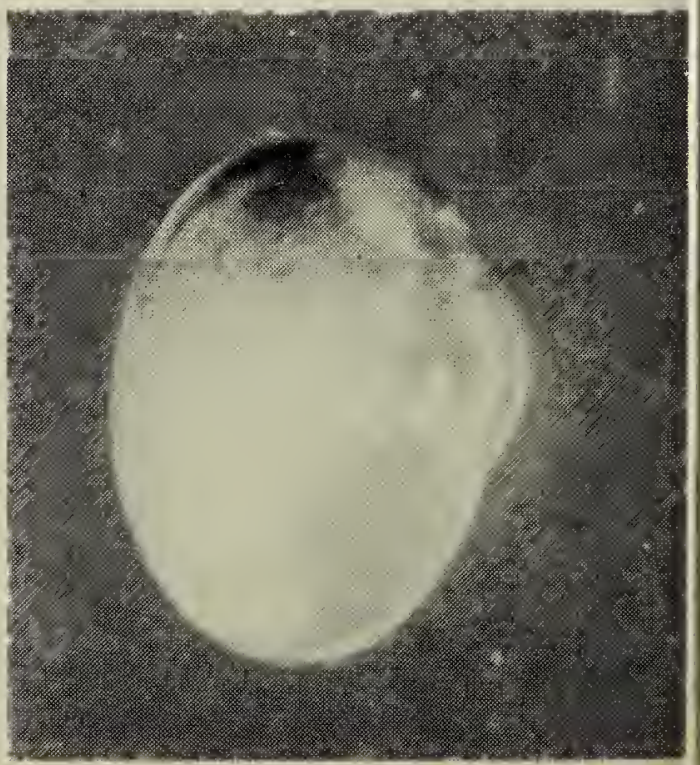


TABLE 1: Invertebrate fauna observed in Potato Lake near La Ronge, Saskatchewan Gordiida (horsehair worms) Gordius

Oligochaeta (aquatic earthworm): Naididae: Chaetogaster, Nais, Styleria Tufificidae: Tubifex tubifex (figure 1 a) Lumbriculidae: Lumbriculus

Hirudinea (leeches): Glossiphoniidae: Helobdella stagnolis (figure 1b)

Erpobdellidae: Erpobdella punctata, Nephelopsis obscura

Crustacea: Cladocera: Daphnia pulex (figure 1c) Daphnia similis, Eurycercus, Polyphemus (figure 1d)

Copepoda: Calanoida, Cyclopoida (figure 1e)

Ostracoda: (seed shrimp) (figure 1f)

Amphipoda: Hyalella azteca (sideswimmers) (figure 1g)

Insecta: Ephemeroptera (mayflies): Caenidae: Caenis (figure Th)

Ephemerellidae: Ephemerella

Siphlonuridae: Siphlonurus, Ameletus

Odonata: Aeshnidae (dragon flies): Aeshna

Libellulidae (dragon flies): Libellula, Leucorrhinia, Tetragoneuria

Lestidae (damsel flies): Lestes

Coenagrionidae (damsel flies): Enallagma, Ishnura

Hemiptera: Corixidae: Trichocorixa (water boatmen)

Notonectidae: Notonecta (back swimmers)

Gerridae: Gerris (water striders)

Trichoptera (caddisflies): Psychomyiidae: Polycentropus

Phryganeidae: Banksiola

Leptoceridae: Oecetis

Coleoptera: Dytiscidai: Hydroporus, Rhantus, Dytiscus (predaceious diving beetles) Chrysomelidae: Donacia (leaf beetles) (figure 1i)

Diptera: Tipulidae: Hexatoma, Limnophila (craneflies)

Dixidae: Dixa (dixa midges)

Culicidae: Aedes (mosquitoes) (figure 1j)

Chironomidae: Ablabesmyia, Chironomus, Polypedilum, Procladius (midges)

Heleidae: Alluaudomyia, Bezzia (figure 1k), Atrichopogon (biting midges)

Muscidae: Anthomyiina (true flies)

Collembola: Isotomurus (springtails)

Hydracarina (water mites)

Archinae (spiders)

Gastropoda (snails): Lymnaeidae: Lymnaea

Amnicolidae: Amnicola

Valvatidae: Valvata

Planorbidae: Gyraulus, Promenetus

Ancylidae: Ferrissia (freshwater limpets)

Pelecypoda: Sphaeriidae: Sphaerium, Pisidium (fingernail clams) (figure 1l)

Many of our northern waters produce interesting aquatic life than is usually thought. Many of the taxa are especially interesting since they are not found further south. Specimens such as these can be easily collected by amateur entomologists who are interested in Northern Saskatchewan, using a sweep net. Basic identification can be performed using a good hand lens and a general key such as the one by Pennak.

Mr. Cliff Adams, University of Alberta, is gratefully acknowledged for the photography.

PENNAK, R. W. 1953. Freshwater Invertebrates of the United States. The Ronald Press Co., New York. 